\title{
Biochar as a growing media additive and peat substitute
}

\author{
C. Steiner ${ }^{1}$ and T. Harttung ${ }^{2}$ \\ ${ }^{1}$ University of Kassel, Organic Plant Production and Agroecosystems Research in the Tropics and Subtropics, Steinstr. 19, \\ 37213 Witzenhausen, Germany \\ ${ }^{2}$ BlackCarbon A/S, Barritskov 36, Barritskovvej, 7150 Barrit, Denmark
}

Correspondence to: C. Steiner (steiner@uni-kassel.de)

Received: 26 February 2014 - Published in Solid Earth Discuss.: 9 April 2014

Revised: 23 July 2014 - Accepted: 23 July 2014 - Published: 22 September 2014

\begin{abstract}
Environmental concerns raised the demand for alternative growing media substituting Sphagnum peat. However growing media formulations still depend on peat and alternatives are limited. Biochar is carbonized plant material and could be an appropriate additive or even substitute for Sphagnum peat. Freshly produced, it is free from pathogens, has a low nutrient content (if produced from nutrient-poor feedstock), a very high structural stability and likely other favourable properties such as air capacity and water-holding capacity.

Preliminary tests were conducted to compare biochar with other growing media and growing media additives. The growth of a miniature sunflower, $\mathrm{pH}$ and electrical conductivity (EC) was measured in different growing media such as biochar, perlite, clay granules, Sphagnum peat and peat mixed with biochar in the ratios $1: 4,1: 1$ and $4: 1(25,50$ and $75 \%$, by volume).

Fresh biochar has a similar EC to peat which is even lower after rinsing with water. Due to the relatively high $\mathrm{pH}$ of biochar, it could be added to peat instead of lime in a concentration of up to $75 \%$. The growth of the sunflower was similar in all growing media. Only the plant weight was slightly higher of plants that grew in perlite or peat. There is a large potential for optimization such as selection of particle size and feedstock for biochar production and growing media formulations for specific plant requirements.
\end{abstract}

\section{Introduction}

Worldwide approximately 11 million metric tons of Sphagnum peat are used for horticultural purposes per year (Apodaca, 2013). Although there are efforts to develop alternative growing media, peat remains to be by far the most important substrate and frequently the sole ingredient of growing media formulations. Peat is still available in large quantities, and modern horticulture depends on quality-assured growing media. The favourable characteristics of horticultural peat are its large water-holding capacity (WHC), its high air capacity at $100 \%$ WHC, the homogeneity and availability of the product, the absence of weed seeds and pathogens, its low bulk density, low $\mathrm{pH}$, low microbiological activity, and low nutrient contents (Reinhofer et al., 2004; Schmilewski, 2008; Michel, 2010). The low $\mathrm{pH}$ and nutrient content is desired as it facilitates to adjust the media to meet the plant-specific requirements by liming and fertilizing.

However the environmental concerns are rising as peat bogs are valuable habitats, important carbon (C) stocks and they provide environmental services such as regulation of the local water quality and water regime or flood protection (Alexander et al., 2008). Peat and the $\mathrm{C}$ contained in it is protected from mineralization by its anoxic and acidic environment. As long as peat remains in its natural and undisturbed habitat, its mineralization is very slow and peatlands are therefore mostly natural $\mathrm{C}$ sinks. However it decomposes quickly and becomes a source of greenhouse gases (GHGs) once the peatland is drained, peat extracted, aerated, limed and fertilized (Cleary et al., 2005). Therefore the conservation of peatlands has gained importance in recent years, and it is likely that peat use in growing media is further restricted (Rivière and Caron, 2001).

However most alternatives are still inconsistent, have a low structural stability and cause nitrogen $(\mathrm{N})$ immobilization, contain too many nutrients (e.g. compost) or have a low water-holding capacity (Reinhofer et al., 2004). The search for substitutes remains as long as there is no material 
suitable to substitute peat entirely (Reinhofer et al., 2004; Schmilewski, 2008; Michel, 2010).

Biochar produced from nutrient-poor feedstock such as wood has a low nutrient content (Gaskin et al., 2008) and an exceptional structural stability (Tian et al., 2012) and is extremely recalcitrant against microbial decay (Kuzyakov et al., 2009). Therefore wood biochar produced at elevated temperature is unlikely to induce $\mathrm{N}$ immobilization, is free from seeds and pathogens and would not provide significant amounts of nutrients. Dumroese et al. (2011) enhanced hydraulic conductivity and improved water availability by adding $25 \%$ pelletized biochar to peat. Biochar was also successfully used to replace perlite in growing media (Northup, 2013). However biochar has mainly been researched as a soil improver in relatively low concentrations. Little information is available on its performance as an additive or even substitute for peat. Therefore this trial aimed to test biochar as growing media, and we hypothesized that biochar performs as well as other growing media with similar physical characteristics.

\section{Materials and methods}

\subsection{Biochar properties}

BlackCarbon A/S in Denmark produces biochar from crushed wooden boxes in continuous flow with combined heat and power production. The biochar is a co-product from energy generation (heat and power), and therefore the temperature is adjusted to optimize both energy and biochar production. Approximately $25 \mathrm{~kg}$ of biochar are produced per hour. The biomass was heated to a maximum temperature of $600^{\circ} \mathrm{C}$, the producer gas had a temperature of $460{ }^{\circ} \mathrm{C}$ and the mean residence time of the feedstock was $1 \mathrm{~h}$. This feedstock is free from bark and has minimal ash content. The resulting biochar seems to be appropriate to be used as a peat substitute, with an average carbon (C) content of $91 \%$ and a very low ash $(1.8 \%)$ content (Table 1$)$. Therefore the electrical conductivity (EC) of the freshly produced biochar is low $(612 \mu \mathrm{S})$ in comparison to other biochars (e.g straw biochar $>16 \mathrm{mS}$ ). The relatively high production temperature reduces the proportion of labile carbon (Antal and Grønly, 2003) which would influence the effective $C: N$ ratio negatively. This biochar was used for simple growing experiments without modification or post-treatment. The particle sizes ranged from 5 to $30 \mathrm{~mm}$, and the airspace of the media was therefore relatively large.

\subsection{Sunflower growing trials}

Two different experiments were set up. One experiment compared biochar with perlite and clay granules, which are similar growing media and growing media additives. The other experiment assessed the performance of biochar and
Table 1. Properties of the biochar and feedstock (wood chips) used for biochar production. (Khanal, 2011; Wiedner et al., 2013).

\begin{tabular}{lll}
\hline & Wood chips & Biochar \\
\hline Carbon (C) \% & 49.5 & 91.2 \\
Nitrogen (N) \% & 0.12 & 0.42 \\
Phosphorous (P) g kg & na & 0.21 \\
Potassium (K) g kg & na & 2.3 \\
Ash \% & 0.4 & 1.8 \\
Loss on ignition (LOI) \% & na & 96.8 \\
Moisture \% & na & 1.4 \\
\hline
\end{tabular}

na: not assessed.

biochar-peat mixtures $0 \%, 25 \%, 50 \%, 75 \%$ and $100 \%$ by volume (Table 2).

Three seeds of a mini sunflower (Helianthus annuus, Teddy Bear) were directly planted in the growing media, and the plants were reduced to 1 plant per pot 3 weeks after planting. Water stress was avoided by daily irrigation. The applied water was dosed with a beaker, and all treatments received equal amounts of irrigation water. In order to avoid any growth limitations by nutrient deficiencies, the biochar-peat mixtures were fertilized with a slow release conventional fertilizer (Osmocote, 17-9-11,-2 NPK, Mg + TE, Scotts Celaflor GmbH and Co. KG, $20 \mathrm{~mL}$ per litre of substrate). The peat was used limed $(20 \mathrm{~mL}$ per litre substrate) or without liming. Biochar was used as produced or with reduced $\mathrm{pH}$ by adding $20 \mathrm{~mL}$ of leonardite (humic and fulvic acids, Humintech GmbH, Düsseldorf, Germany) per litre of substrate. Clay granules (Seramis ${ }^{\circledR}$, Mars $\mathrm{GmbH}$, Mogendorf, Germany) are used as growing media, and the product is sold with specific fertilizer formulations. In order to compare biochar with clay granules and perlite, the Seramis fertilizer was used for all growing media as recommended. The plants were grown in $1 \mathrm{~L}$ pots and arranged in a Latin square (four treatments and four replicates). The experiment with biochar-peat mixtures was arranged in a randomized complete block design with four replicates.

\subsection{EC and $\mathrm{pH}$ of the growing media}

Biochar, peat, coco coir and the different mixtures $(25,50$ and $75 \%$, by volume) were measured with three replicates. EC was measured using the PCE-CM 41 (PCE Deutschland $\mathrm{GmbH}$, Germany) conductivity meter, and for $\mathrm{pH}$ measurements the $\mathrm{pH}$ meter PCE-PH20S was used. This $\mathrm{pH}$ meter was developed for directly determining the $\mathrm{pH}$ value of soil. The biochar substrate consists of stiff pieces and coarse airfilled pores. Therefore an extraction was necessary.

A combination of the saturated media extraction and the pour-through method was used for $\mathrm{EC}$ and $\mathrm{pH}$ measurements. Plastic (PP) cups with a volume of $350 \mathrm{~mL}$ were perforated at the bottom and filled with substrate. These cups were stacked into $350 \mathrm{~mL}$ cups without perforation and filled 
Table 2. Treatments and experimental setup.

\begin{tabular}{|c|c|c|c|c|}
\hline & Growing media & Fertilization & Additives & Replicates $(n)$ \\
\hline \multirow{4}{*}{ Experiment 1} & Seramis & Seramis & & 4 \\
\hline & Perlite & Seramis & & 4 \\
\hline & Biochar & Seramis & & 4 \\
\hline & Biochar & Seramis & Leonardite $\left(20 \mathrm{mLL}^{-1}\right)$ & 4 \\
\hline \multirow{7}{*}{ Experiment 2} & Peat & Osmocote & & 4 \\
\hline & Peat & Osmocote & Lime $\left(20 \mathrm{~mL} \mathrm{~L}^{-1}\right)$ & 4 \\
\hline & $25 \%$ biochar, $75 \%$ peat & Osmocote & & 4 \\
\hline & $50 \%$ biochar, $50 \%$ peat & Osmocote & & 4 \\
\hline & $75 \%$ biochar, $25 \%$ peat & Osmocote & & 4 \\
\hline & Biochar & Osmocote & & 4 \\
\hline & Biochar & Osmocote & Leonardite $\left(20 \mathrm{~mL} \mathrm{~L}^{-1}\right)$ & 4 \\
\hline
\end{tabular}

with distilled water. After approximately $3 \mathrm{~h}$ the perforated cup was lifted and the water drained into the second nonperforated cup. The collected water was used to measure EC and $\mathrm{pH}$.

The pour-through method was used or $\mathrm{pH}$ and EC readings if the fertilized media was measured during the sunflower growth trials 6 weeks after planting. The media was wetted until just saturated and left to stand for about two hours. Then, a volume of water sufficient to produce enough leachate for $\mathrm{EC}$ and $\mathrm{pH}$ measurement $(100 \mathrm{~mL})$ was applied to the pot. EC and $\mathrm{pH}$ was measured in the collected leachate.

To assess the maximum water-holding capacity and drying characteristics, the medias clay granules, biochar, peat and a $1: 1$ biochar-peat mixture (by volume) were soaked in water for $24 \mathrm{~h}$, then drained and left for drying. The weight loss of the $350 \mathrm{~mL}$ cups was recorded regularly.

\subsection{Statistics}

Plots were made with SigmaPlot 12 . Homogeneity of variances, one-way analysis of variance and least significant difference post hoc tests were performed with IBM SPSS Statistics, version 20.

\section{Results and discussion}

\subsection{EC and pH}

Due to a high $\mathrm{pH}$ of the biochar $(\mathrm{pH} 9)$, it served as a substitute for lime. Biochar peat blends can contain up to $80 \%$ biochar without raising the $\mathrm{pH}$ above 7 (Fig. 1).

The initial EC of biochar $\left(612 \mu \mathrm{S} \mathrm{cm}^{-1}\right)$ was similar to that of the unfertilized peat $\left(633 \mu \mathrm{S} \mathrm{cm}^{-1}\right)$ and was reduced to $380 \mu \mathrm{S} \mathrm{cm}^{-1}$ and $415 \mu \mathrm{S} \mathrm{cm}^{-1}$ respectively, after rinsing with distilled water. Biochar which was used for 2 months as growing substrate had an average EC of $360 \mu \mathrm{S} \mathrm{cm}^{-1}$. The EC of both the pure biochar as well as the pure peat was approximately $1 / 3$ higher than that of the mixtures $(25,50$ and $75 \%)$ before $\left(470,446,352 \mu \mathrm{S} \mathrm{cm}^{-1}\right)$ and after rins-

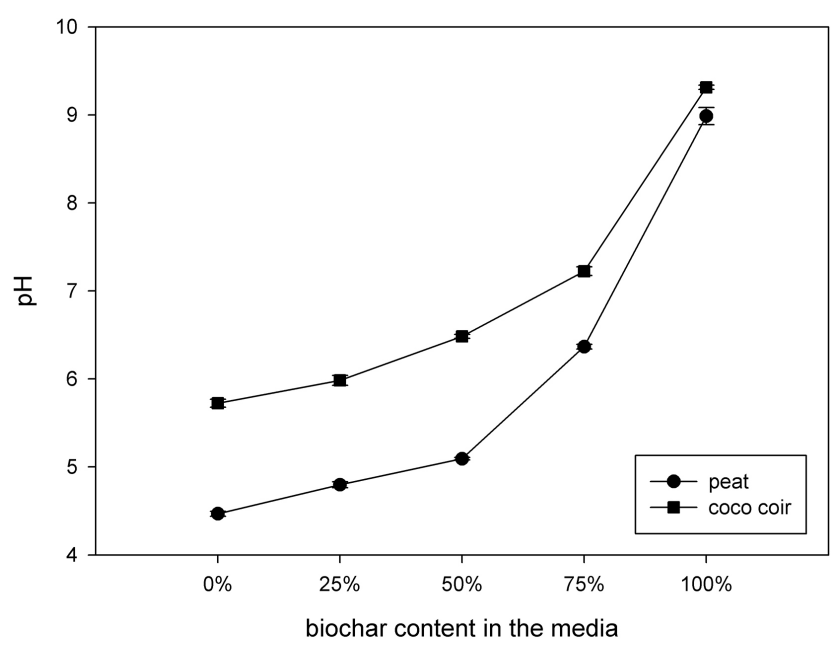

Figure 1. Changes in $\mathrm{pH}$ with increasing rates of biochar added to peat or coconut coir ( $n=3$, error bars: standard deviation).

ing $\left(236,253\right.$ and $\left.229 \mu \mathrm{S} \mathrm{cm}^{-1}\right)$ with distilled water. Adding $10 \%$ leonardite reduced the $\mathrm{pH}$ of pure biochar to 5.2 but increased the EC up to $3 \mathrm{mS} \mathrm{cm}^{-1}$. A $5 \%$ leonardite addition is sufficient to reduce the $\mathrm{pH}$ below 7, but increases the $\mathrm{EC}$ to $1.5 \mathrm{mS} \mathrm{cm}^{-1}$. The water retention of the biochar was similar to that of the clay granules. If the biochar was mixed with peat ( $1: 1$ by volume, Fig. 2), it did not change the water uptake and drying characteristics, compared to the peat without biochar addition.

Most likely due to leaching of excess salts (ashes) and plant uptake, 6 weeks after planting the growing media clay granules, biochar, biochar $+\mathrm{HA}$ and perlite had the same $\mathrm{pH}$ and $\mathrm{EC}$ (means, 7.7 and $827 \mu \mathrm{S} \mathrm{cm}^{-1}$, respectively). The HA had no lasting effect on $\mathrm{pH}$ and EC. The growing media with peat and biochar had significantly different $\mathrm{pH}$ values. Liming increased the $\mathrm{pH}$ significantly. Surprisingly, biochar reduced (25\% addition) and increased the $\mathrm{pH}$ in mixtures with peat at higher concentration compared to peat. The media with $25 \%$ biochar addition had a significantly lower $\mathrm{pH}$ than 


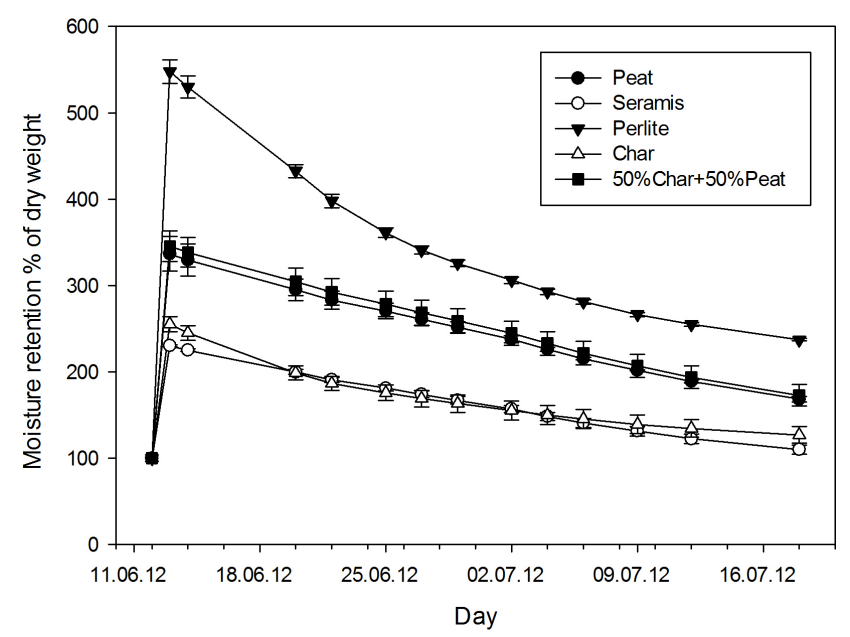

Figure 2. Moisture uptake and drying of different growing media (peat, clay granules, perlite, biochar, and biochar mixed with peat, $n=3$, error bars: standard deviation).
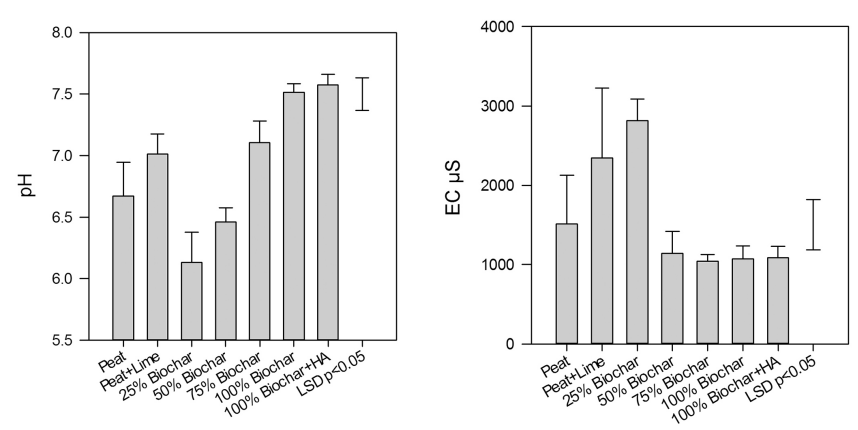

Figure 3. pH (left) and EC (right) of peat, limed peat, biochar and biochar-peat mixtures in leachate 6 weeks after planting $(n=4$, means and standard deviation, HA: humid acid, leonardite, LSD: least significant difference).

peat. A $50 \%$ addition did not influence the $\mathrm{pH}$ significantly; in comparison the pure peat and a $75 \%$ addition had a significantly higher $\mathrm{pH}$ (Fig. 3). The EC increased significantly if the peat was limed or amended with $25 \%$ biochar, but was lower in the $50 \%, 75 \%$ mixtures and pure biochar treatments (Fig. 3b).

\subsection{Sunflower growing performance}

The average plant height at harvest did not differ significantly between the treatments $(43,44.5,43.4,45.6 \mathrm{~cm}$ for clay granules, biochar, biochar + HA and perlite respectively). However the mean fresh weight of plants growing in perlite was significantly higher $(p<0.05,92.3 \mathrm{~g})$ followed by clay granules $(81.7 \mathrm{~g})$, biochar $(76.6 \mathrm{~g})$ and biochar + HA $(69.2 \mathrm{~g})$. Acidification with HA did not improve plant growth.

The plants growing in peat and biochar-peat mixtures had the same size. Only the weight of the plants differed significantly (Fig. 4). The heaviest plants grew in limed peat

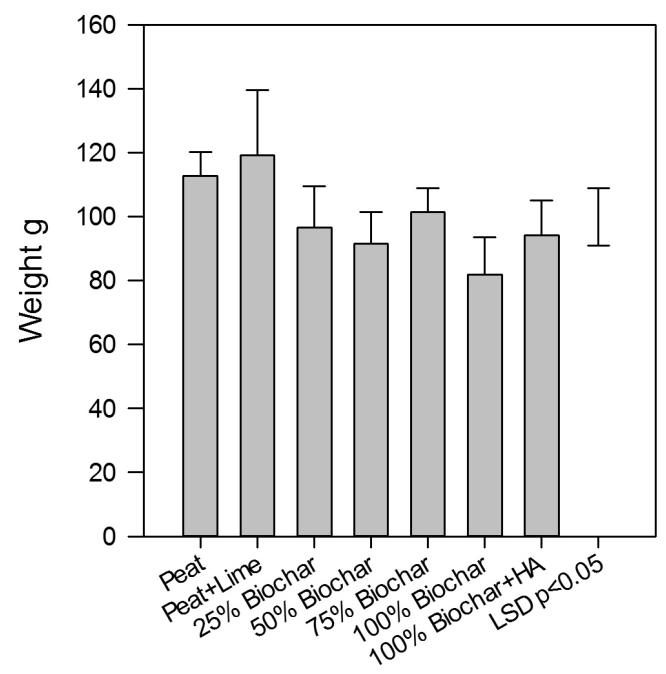

Figure 4. Fresh weight of miniature sunflowers grown in peat, limed peat, biochar and biochar-peat mixtures in leachate 6 weeks after planting ( $n=4$, means and standard deviation, HA: humid acid, leonardite, LSD: least significant difference).

followed by peat without lime. However the difference was small and the weight of plants growing in media with $75 \%$ biochar addition was not significantly reduced, and that with a $25 \%$ biochar addition was not significantly different from plants grown in peat without lime.

Dumroese et al. (2011) used pelletized biochar as an additive to growing media. The pellets contained $43 \%$ wood flour, $7 \%$ polyacidic acid, and $7 \%$ starch. Therefore they significantly increased the effective $\mathrm{C}: \mathrm{N}$ ratio. Further the pellets had a high bulk density and water adsorption caused swelling of the media. Pelletizing is not necessary if the biochar is used in pieces. Considering that biochar was used without modification in relatively coarse pieces, biochar performed remarkable well as growing media. Particle size and type of biochar most likely influence the physical characteristics of the media, and there is considerable scope for optimization.

\subsection{Avoided GHG emissions due to substitution of peat with biochar}

The decay of biochar is extremely slow (Kuzyakov et al., 2009). Therefore carbonization decelerates the $C$ cycle and sequesters $\mathrm{C}$ for relatively long periods of time. In addition $\mathrm{C}$ emissions associated with the decay of peat would be avoided if biochar replaced peat. Furthermore the pyrolysis process to produce biochar could provide renewable energy (for instance to heat greenhouses) substituting fossil fuels. However, the emissions from the decay of horticultural peat are only assessed in the United Kingdom (Barthelmes et al., 2009). 
The potential for emissions reductions from substituting fossil fuels depends on the type of fuel replaced and on the pyrolysis technology used. The average $\mathrm{C}$ content of the biochar used in these trials is $85 \%$ and has an estimated labile carbon content of $10 \%$. Consequently 1 metric ton would sequester approximately $2.8 \mathrm{Mg}$ of $\mathrm{CO}_{2 \mathrm{e}}$.

Processing and transport of both biochar and peat requires fossil-fuel-based energy. Transport pathways are most likely shorter for biochar, in particular when the production unit resides with the feedstock source and consumption site. Therefore, for simplicity, only the carbon contained in peat and released as $\mathrm{CO}_{2}$ during its decay is used for this calculation (neglecting the likely larger harvest and transportation costs for peat). One milligram of peat contains approximately $500 \mathrm{~kg}$ of carbon corresponding to $1.7 \mathrm{Mg}$ of $\mathrm{CO}_{2 \mathrm{e}}$ after its decay. The IPCC's 100-year time horizon is the standard reporting time frame and assumes that all organic material will decompose within 100 years (IPCC, 2006). Peat and other growing media are used in volume rather than dry weight. The biochar produced from pine chips had a bulk density of $0.15 \mathrm{~g} \mathrm{~cm}^{-3}$ : it can be very similar to that of peat substrates (Pindstrup Mosebrug A/S, personal communication, 2011). Under this assumption, the replacement of peat with biochar could avoid $4.5 \mathrm{MgCO}_{2 \mathrm{e}} \mathrm{Mg}^{-1}$ of peat substituted.

\section{Conclusions}

Not all biochars may be suitable as peat substitutes. Some feedstocks (e.g. poultry litter) are rich in minerals, and produce biochars with high $\mathrm{pH}$ values and salt (ash) content. That is, they would cause osmotic stress in plants when used in larger amounts. However, biochar produced from pure wood has very low ash content (Gaskin et al, 2008). The EC of the biochar used in this study was similar to that of unfertilized peat $\left(612 \mu \mathrm{S} \mathrm{cm}^{-1}\right.$ and $633 \mu \mathrm{S} \mathrm{cm}^{-1}$ respectively). When this biochar is mixed with peat, the blend could contain up to $80 \%$ biochar without raising the $\mathrm{pH}$ above 7 . The growth of a miniature sunflower was similar in perlite, clay granules (Seramis), peat and peat-biochar mixtures. Peatbased growing media are acidic and limed to adjust the $\mathrm{pH}$. If biochar is used as an additive to peat, it could replace lime. The biochar was used without any further modification. Adjusting $\mathrm{pH}$ and the selection of ideal particle sizes needs further research and enables optimization.

\section{The Supplement related to this article is available online} at doi:10.5194/se-5-995-2014-supplement.

\section{References}

Alexander, P. D., Bragg, N. C., Meade, R., Padelopoulos, G., and Watts, O.: Peat in horticulture and conservation: the UK response to a changing world, Mires Peat, 3, 1-10, 2008.

Antal, M. J. and Grønli, M.: The art, science, and technology of charcoal production, Indust. Engineer. Chem. Res., 42, 16191640, 2003.

Apodaca, L. E.: Peat, US Department of the Interior, Reston, Virginia, 1-8, 2013.

Barthelmes, A., Couwenberg, J., and Joosten, H.: Peatlands in National Inventory Submissions 2009 - An analysis of 10 European countries, Greifswald University, 28, 2009.

Cleary, J., Roulet, N. T., and Moore, T. R.: Greenhouse gas emissions from Canadian peat extraction 1990-2000: a life-cycleanalysis, Ambio, 34, 456-461, doi:10.1579/0044-7447-34.6.456, 2005.

Dumroese, R. K., Heiskanen, J., Englund, K., and Tervahauta, A.: Pelleted biochar: Chemical and physical properties show potential use as a substitute in container nurseries, Biomass Bioenergy, 35, 2018-2027, 2011.

Gaskin, J. W., Steiner, C., Harris, K., Das, K. C., and Bibens, B.: Effect of low-temperature pyrolysis conditions on biochar for agricultural use, T. ASABE, 51, 2061-2069, 2008.

IPCC: Chapter 7, in: Wetlands, Intergovernmental Panel on Climate Change, Switzerland, 2006.

Khanal, G. C.: Effects of biochar on soil microbial activity and greenhouse gas emissions, Master Thesis, Aarhus University, 2011.

Kuzyakov, Y., Subbotina, I., Chen, H., Bogomolova, I., and Xu, X.: Black carbon decomposition and incorportaion into soil microbial biomass estimated by ${ }^{14} \mathrm{C}$ labeling, Soil Biol. Biochem., 41, 210-219, doi:10.1016/j.soilbio.2008.10.016, 2009.

Michel, J.-C.: The physical properties of peat: a key factor for modern growing media, Mires Peat, 6, 1-6, 2010.

Northup, J.: Biochar as a replacement for perlite in greenhouse soilless substrates, Graduate Theses and Dissertations, Paper 13399 , Iowa State University, 2013.

Reinhofer, M., Lettmayer, G., and Taferner, K.: Torferstatzprodukte Torfersatz durch biogene Rest- und Abfallstoffe - Vorprojekt, Endbericht - Modul B, Institut fuer Nachhaltige Techniken und System - Joints, Frohnleiten, Austria, 44, 2004.

Rivière, L. M. and Caron, J.: Research on substrates: state of the art and need for the coming 10 years, Acta Hort., 548, 29-42, 2001.

Schmilewski, G.: The Role of peat in assuring the quality of growing media, Mires Peat, 3, 1-8, 2008.

Tian, Y., Sun, X., Li, S., Wang, H., Wang, L., Cao, J., and Zhang, L.: Biochar made from green waste as peat substitute in growth media for Calathea rotundifola cv. Fasciata, Sci. Horticult., 143, 15-18, doi:10.1016/j.scienta.2012.05.018, 2012.

Wiedner, K., Rumpel, C., Steiner, C., Pozzi, A., Maas, R., and Glaser, B.: Chemical evalutation of chars produced by thermochemical conversion (gasification, pyrolysis and hydrothermal carbonization) of agro-industrial biomass on a comercial scale, Biomass Bioenergy, 59, 264-278, 2013. 